\title{
Assessment of metals concentrations in dairy feed collected from urban and rural areas dairy farms
}

\author{
Abdul Waheed Ghanghro* \\ Institute of Biochemistry University of Sindh Jamshoro, Sindh Jamshoro-Pakistan \\ *Corresponding author's email: $\underline{\text { abdulwaheed@usindh.edu.pk }}$ \\ Citation \\ Abdul Waheed Ghanghro. Assessment of metals concentrations in dairy feed collected from urban and rural \\ areas dairy farms. Pure and Applied Biology. Vol. 9, Issue 2, pp1510-1514. \\ http://dx.doi.org/10.19045/bspab.2020.90157
}

\begin{tabular}{llll}
\hline \hline Received: 01/12/2019 & Revised: 25/02/2020 & Accepted: 02/03/2020 & Online First: 13/03/2020 \\
\hline
\end{tabular}

\section{Abstract}

Metals contamination in animal feed is one of the major issues for animal's health and performance because these toxic metals may accumulate in various organs of animal. The present study was aimed to determine the various concentrations of selected metals copper $(\mathrm{Cu})$, Zinc (Zn), Cadmium (Cd), Lead (Pb), Manganese (Mn) and Nickel (Ni) in 60 dairy feed samples collected from urban and rural areas of District Jamshoro Sindh by applying atomic absorption spectrophotometer (AAS). Significantly higher levels of $\mathrm{Cu}, \mathrm{Zn}, \mathrm{Cd}, \mathrm{Pb}, \mathrm{Mn}$ and $\mathrm{Ni}$ were obtained in dairy feeds collected from urban areas of Jamshoro. Mean levels of metals in dairy feeds were in the order of $\mathrm{Zn}>\mathrm{Cu}>\mathrm{Pb}>\mathrm{Cd}>\mathrm{Mn}>\mathrm{Ni}$ and $\mathrm{Zn}>\mathrm{Cu}>\mathrm{Cd}>\mathrm{Ni}>\mathrm{Pb}>\mathrm{Mn}$ in both areas. Significantly negative association for $\mathrm{Zn}-\mathrm{Cd}(\mathrm{r}=-0.463), \mathrm{Zn}-\mathrm{Mn}(\mathrm{r}=-0.349)$ and $\mathrm{Zn}-\mathrm{Cd}$ $(\mathrm{r}=-0.361)$ and $\mathrm{Zn}-\mathrm{Ni}(\mathrm{r}=-0.377)$ positive association for $\mathrm{Cd}-\mathrm{Mn}(\mathrm{r}=0.307)$ and $\mathrm{Mn}-\mathrm{Ni}(\mathrm{r}=0.22)$ were found in between the concentrations of metals in both areas dairy feed samples. In cluster analysis (CA) metals were grouped in three main clusters indicating their same source of origin.

Keywords: Dairy feed; Metals; Rural; Urban area

\section{Introduction}

Metal contamination in animal feed is considered as a major threat for animal health and performance. Heavy metals like $\mathrm{Cu}, \mathrm{Cd}, \mathrm{Pb}$ and $\mathrm{Cr}$ are well known as bioaccumulative toxicants and cause serious health issues in animals even at low concentration [1, 2]. Expulsion of sewage and industrial waste is one of the serious issues of Pakistan; it is regular practice that significant squanders are released into agricultural land, which may cause the metals contamination in agricultural products [3]. Industrial effluents, municipal sewage and concrete waste carried by way of drains and canals to causes the water and land pollution in different areas of country. Number of studies like [4-6] has reported transfer of heavy metals from soil and water into food chain. However little information is available about the metals contamination in dairy feed in Pakistan that's why present study was aimed to determine the metals concentrations in dairy feed samples collected from urban and rural areas of District Jamshoro Sindh.

Materials and methods

Feed samples collection

For present study a total of $(n=60)$ dairy feed samples were collected from two sites of Jamshoro $(n=30)$ from urban areas dairy farms and $(n=30)$ from rural areas dairy farms. All the samples were collected in $\mathrm{HNO}_{3}$ washed plastic type bags.

Feed samples preparation for metals analysis 
All the dairy feed samples were prepared for metals analysis by using Association of Official Analytical Chemistry [7] recommended method. One gram of each dairy feed sample was digested by adding $10 \mathrm{ml}$ of concentrated $\mathrm{HNO}_{3}$ for $24 \mathrm{hrs}$ and then solution was heated at $200^{\circ} \mathrm{C}$ till clear extract was obtained. The final clear extract was diluted with double distilled water up to $20 \mathrm{ml}$ and then filtered for final analysis. All the selected metals were measured by using Atomic absorption spectrophotometer (AAS).

\section{Statistical analysis}

The metals concentrations in dairy feed samples were expressed as minimum, maximum and mean \pm SD. The data was analyzed by using SPSS version 16 . Two ways analysis of variance was used tom analyze the data for calculating difference between the metals concentrations in dairy feeds collected from urban and rural areas of Jamshoro. Correlations between the metals were determined by using Pearson's coefficient correlation.

\section{Results and discussion}

Metals concentrations in dairy feed samples

Average concentration of selected metals $\mathrm{Cu}, \mathrm{Zn}, \mathrm{Cd}, \mathrm{Pb}, \mathrm{Mn}$ and $\mathrm{Ni}$ in dairy feed samples collected from urban and rural areas of Jamshoro is summarized in (Table1).

Table 1. Concentration $(\mathrm{mg} / \mathrm{kg})$ of metals in feed samples collected from urban and rural areas of Jamshoro

\begin{tabular}{|c|c|c|c|c|c|c|c|}
\hline \multicolumn{5}{|c|}{ Urban area } & \multicolumn{4}{c|}{ Rural area } \\
\hline Metal & Min & Max & Mean \pm SD & Min & Max & Mean \pm SD & P-value \\
\hline $\mathrm{Cu}$ & 2.09 & 20.56 & $12.481 \pm 4.75$ & 4.71 & 17.37 & $9.568 \pm 3.40$ & $<0.01^{* *}$ \\
\hline $\mathrm{Zn}$ & 8.53 & 26.43 & $14.671 \pm 4.80$ & 7.03 & 20.02 & $11.326 \pm 3.35$ & $<0.01^{* *}$ \\
\hline $\mathrm{Cd}$ & 0.23 & 3.56 & $1.696 \pm 0.86$ & 0.18 & 2.78 & $1.024 \pm 0.66$ & $<0.01^{* *}$ \\
\hline $\mathrm{Pb}$ & 0.22 & 3.67 & $1.705 \pm 0.90$ & 0.13 & 2.44 & $0.484 \pm 0.52$ & $<0.01^{* *}$ \\
\hline $\mathrm{Mn}$ & 0.02 & 1.85 & $0.615 \pm 0.50$ & 0.01 & 1.22 & $0.291 \pm 0.35$ & $0.05^{*}$ \\
\hline $\mathrm{Ni}$ & 0.31 & 2.45 & $1.128 \pm 0.41$ & 0.08 & 2.02 & $0.732 \pm 0.55$ & $<0.01^{*}$ \\
\hline
\end{tabular}

Significant $(\mathrm{P}<0.01)^{*}, \quad$ Significant $(\mathrm{P}<0.05)^{*}$

\section{Copper (Cu)}

Average copper level in urban areas dairy feed samples was $12.481 \pm 4.75 \mathrm{mg} / \mathrm{kg}$ compared to $9.568 \pm 3.40 \mathrm{mg} / \mathrm{kg}$ in dairy feed from rural areas. Significantly $(\mathrm{P}<0.01)$ higher values of copper were obtained in urban areas dairy feeds. The reported values of copper in dairy feed samples were within their recommended range of [8]. Variation in copper level in both areas feed may be due to use of copper sulphate as additive in feed. The reported values of copper in present study were lower than those reported by $[\mathbf{9}, \mathbf{1 0}]$ in China and USA.

\section{Zinc (Zn)}

$\mathrm{Zn}$ is one of the important mineral required for the different physiological activities of body [11]. Average concentration of zinc was $14.671 \pm 4.80 \mathrm{mg} / \mathrm{kg}$ in dairy feed collected from urban areas compared to $11.326 \pm 3.35 \mathrm{mg} / \mathrm{kg}$ in dairy feed collected from rural areas. Significantly $(\mathrm{P}<0.01)$ higher level of copper was found in urban areas feed samples. Comparably zinc level in both areas feed samples was below the permissible limits $50 \mathrm{mg} \mathrm{kg}$ of WHO/FAO.

\section{Cadmium (Cd)}

Cadmium is non-essential toxic metal, widely distributed in soil and easily taken up by the different plant from soil [13]. Mean concentration of cadmium in dairy feed collected from urban areas was $1.696 \pm 0.86 \mathrm{mg} / \mathrm{kg}$ compared to $1.024 \pm 0.66$ $\mathrm{mg} / \mathrm{kg}$ in dairy feed collected from rural areas. Significantly $(\mathrm{P} \leq 0.01)$ higher level of cadmium in urban areas feed may be associated with anthropogenic sources especially agricultural activities, usage of 
waste water and heavy vehicular emission. A Number of studies from Pakistan [14-16] had reported higher level of metals in water and soil of different parts of country.

\section{Lead $(\mathbf{P b})$}

Average concentration of lead in dairy feed collected from urban areas was 1.705 \pm 0.90 $\mathrm{mg} / \mathrm{kg}$ compared to $0.975 \pm 0.62 \mathrm{mg} / \mathrm{kg}$ in rural areas feed samples. Significantly $(\mathrm{P}<0.001)$ higher level of lead was found in urban areas feed samples. The values obtained for lead in this study were below the toxic level of [8]. Increased level of lead in urban areas feed samples may be associated with high amount of lead in soil and water used for the cultivation. Lead content in feed and plants is largely due to atmospheric deposition of lead in soil. Majority of plants are capable of taking lead from soil through their roots [17].Current values of lead in both areas feed samples were lower than those reported by $[18, \mathbf{1 9}]$.

\section{Manganese (Mn)}

Manganese is an essential mineral required for activation of enzymes as a component of metalloenzymes [20]. Average concentration of manganese in urban areas feed was $0.615 \pm 0.50 \mathrm{mg} / \mathrm{kg}$ compared to $0.03 \pm 0.05 \mathrm{mg} / \mathrm{kg}$ in feed collected from rural areas. Significantly $(\mathrm{P} \leq 0.05)$ higher concentration of $\mathrm{Mn}$ was found in feed collected from urban areas. Mean manganese level in both areas feed samples were below the critical level of [8].

\section{Nickel (Ni)}

Average nickel concentration in urban feed was $1.128 \pm 0.41 \mathrm{mg} / \mathrm{kg}$ compared to $0.732 \pm 0.55 \mathrm{mg} / \mathrm{kg}$ in the BF collected from rural areas. Significantly $(\mathrm{P} \leq 0.01)$ higher level of Ni content was found in urban areas feed samples. Nickel concentration in feed may increase. In most soils used for agricultural purpose nickel level ranges from 3 to $1000 \mathrm{mg} / \mathrm{k}$, but in polluted areas $\mathrm{Ni}$ level in soil is up to $26000 \mathrm{mg} / \mathrm{kg}$ [21].

\section{Correlation between the metals}

Correlation between the metal concentrations in feed samples collected from urban and rural areas is reported in (Table 2). Significantly $(\mathrm{P}<0.05)$ negative correlation between the concentrations of $\mathrm{Zn}-\mathrm{Cd}$ ( $\mathrm{r}=-0.463), \mathrm{Zn}-\mathrm{Mn}$ ( $\mathrm{r}=-0.349), \mathrm{Zn}-$ $\mathrm{Cd}(\mathrm{r}=-0.361)$ and positive correlation in $\mathrm{Mn}-\mathrm{Cd}(\mathrm{r}=0.307)$ were found in urban areas feed, While only negative correlation between the concentrations of $\mathrm{Zn}-\mathrm{Cd}$ ( $\mathrm{r}=-$ $0.361)$ and $\mathrm{Zn}-\mathrm{Ni}(\mathrm{r}=-0.377)$ were found in rural areas feed.

Table 2. Correlation matrix between the metal concentrations in feed

\begin{tabular}{|c|c|c|c|c|c|c|}
\hline Metals & $\mathbf{C u}$ & Zn & Cd & $\mathbf{P b}$ & Mn & $\mathbf{N i}$ \\
\hline \multicolumn{7}{|c|}{ Urban area } \\
\hline $\mathrm{Cu}$ & 1 & & & & & \\
\hline $\mathrm{Zn}$ & 0.123 & 1 & & & & \\
\hline $\mathrm{Cd}$ & 0.224 & $-0.463 *$ & 1 & & & \\
\hline $\mathrm{Pb}$ & -0.056 & 0.147 & 0.017 & 1 & & \\
\hline $\mathrm{Mn}$ & 0.191 & $-0.349^{*}$ & $0.307 *$ & -0.193 & 1 & \\
\hline $\mathrm{Ni}$ & -0.145 & -0.208 & 0.003 & 0.145 & 0.118 & 1 \\
\hline \multicolumn{7}{|c|}{ Rural area } \\
\hline $\mathrm{Cu}$ & 1 & & & & & \\
\hline $\mathrm{Zn}$ & -0.185 & 1 & & & & \\
\hline $\mathrm{Cd}$ & -0.058 & $-0.361 *$ & 1 & & & \\
\hline $\mathrm{Pb}$ & 0.103 & -0.165 & -0.154 & 1 & & \\
\hline $\mathrm{Mn}$ & 0.126 & 0.007 & -0.197 & 0.018 & 1 & \\
\hline $\mathrm{Ni}$ & 0.191 & $-0.377^{*}$ & 0.004 & -0.010 & 0.221 & 1 \\
\hline
\end{tabular}

* Correlation is significant at 0.05 levels

\section{Hierarchical Clustering analysis (HCA)}


Cluster analysis results as a dendrogram for metal concentrations in dairy feed samples is reported in (Fig. 1 ). The cluster analysis for metals was applied to determine the grouping in measured variables. As the result of dendogram three groups (clusters) were obtained in this study in both areas feed samples. Custer one consists of Ni-Zn-

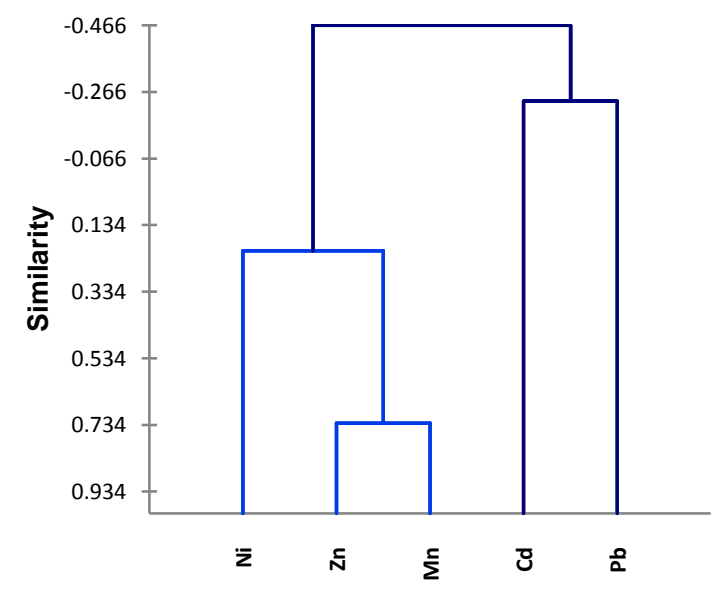

$\mathrm{Mn}$, cluster two include $\mathrm{Cd}$ and cluster three include $\mathrm{Pb}$. Closely clustering between $\mathrm{Ni}, \mathrm{Zn}$ and $\mathrm{Mn}$ indicate they have same source of origin specially the waste water used for their cultivation. Similarly the $\mathrm{Cd}$ and $\mathrm{Pb}$ may be associated with anthropogenic sources in both urban and rural areas of Jamshoro.

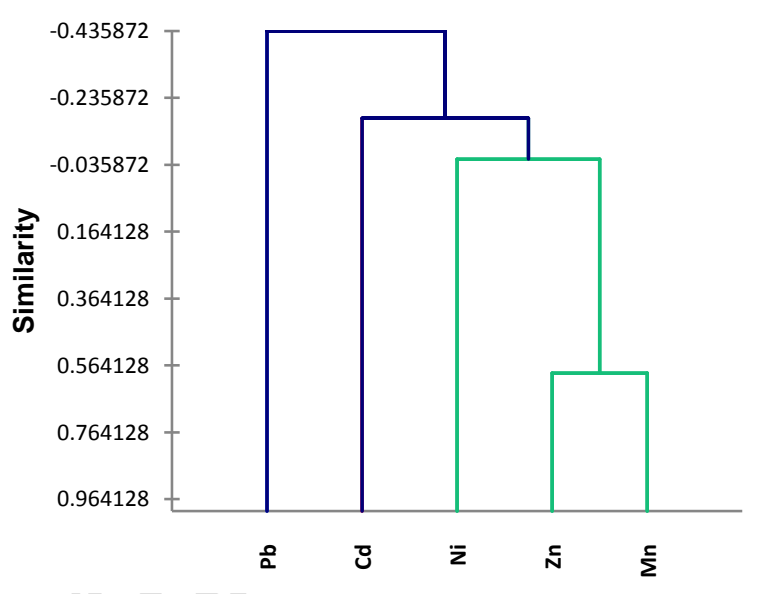

Figure 1. Showing the dendogram obtained from hierarchical clustering analysis for urban and rural areas feed samples

\section{Conclusion}

In present research work level of six selected metals $\mathrm{Cu}, \mathrm{Zn}, \mathrm{Cd}, \mathrm{Pb}, \mathrm{Mn}$ and $\mathrm{Ni}$ were compared in dairy feed collected from urban and rural areas of District Jamshoro. The results revealed that level of selected metals was higher in the dairy feed collected from urban areas compared to rural area. Furthermore it was observed that all the selected metals in both areas dairy feed samples were within their permissible limits. Hierarchical clustering analysis showed that most of the selected metals had same source of origin in both areas.

\section{Authors' contributions}

Conceived and designed the experiments: A Waheed, Performed the experiments: A Waheed, Analyzed the data: A Waheed, Contributed materials/ analysis/ tools: A Waheed, Wrote the paper: A Waheed.

\section{References}

1. Abdul R \& Schroder PM (2009). Implications of metal accumulation mechanisms to phytoremediation.
Environ Sci Pollut Res Int 16: 162175.

2. Ali H, Khan E \& Sajad M (2013). Phytoremediation of heavy metalsconcepts and applications. Chemosp 91(7): 869-881.

3. Hassan UN, Mahmood Q, Waseem A, Irshad M \& Pervez A (2013). Assessment of heavy metals in wheat plants irrigated with contaminated wastewater. Pol J Environ Study 22(1): 115-123.

4. Rozso K, Varhegyi J, Mocsenyi AR \& Fugli K (2003). Lead content of the forages and the effect of lead exposure on ruminants. Vet Bull 73: 510-510.

5. Bansal OP (2004). Uptake of heavy metals by crop plants. Poll Res 23: 501506.

6. Raj BG, Patnaik MC, Babu SP, Kalakumar B, Singh MV \& Shylaja J (2006). Heavy metal contaminants in water-soil-plant-animal continuum due to pollution of Musi River around 
Hyderabad in India. Indian J Anim Sci 76: 131-133.

7. AOAC (1990). Official Methods of Analysis, Association of Official Analytical Chemists, Arlington, Va, USA, 15th edition.

8. NRC, National Research Council (2005). Committee on Minerals and Toxic Substances in Diets and Water for Animals, National Research Council (US) Subcommittee on Mineral toxicity in animals. Mineral tolerance of animals. 2nd ed. National Academic Press Washington DC, pp 496.

9. Zhang F, Li Y, Yang M \& Li W (2012). Content of heavy metals in animal feeds and manures from farms of different scales in northeast China. Int $J$ Environ Res Public Health 9(8): 2658-2668.

10. Dai SY, Jones B, Lee K-M, Li W, Post L \& Herrman TJ. (2016). Heavy metal contamination of animal feed in Texas. J Regulat Sci 1: 21-32.

11. EFSA CONTAM Panel (EFSA Panel on Contaminants in the Food Chain (2015). Scientific Opinion on the risks to public health related to the presence of nickel in food and drinking water. EFSA J 13(2): 4002-4202.

12. EFSA (2004). Opinion of the Scientific Panel on Contaminants in the Food Chain on a request from the $1310 \mathrm{P}$. ADAMSE ET AL. Commission related to cadmium as undesirable substance in animal feed. EFSA $J$ 72: 1-24.

13. Farooqi A, Masuda $\mathrm{H} \&$ Firdous $\mathrm{N}$ (2007). Toxic fluoride and arsenic contaminated groundwater in the Lahore and Kasur districts, Punjab, Pakistan and possible contaminant sources. Environ Poll 145(3): 839849.
14. Manzoor S, Shah MH, Shaheen N, Khalique A \& Jaffar M (2006). Multivariate analysis of trace metals in textile effluentsin relation to soil and groundwater. J Hazard Mater 137(1): 31-37.

15. Ahmad SS \& Erum S (2010). Integrated assessment of heavy metals pollution along motorway M-2. Soil and Environ 29(2): 110-116.

16. Umar M, Waseem A, Sabir MA, Kassi AM \& Khan AS (2013). The Impact of Geology of Recharge Areas on Groundwater Quality: a case study of Zhob River Basin, Pakistan. CleanSoil, Air, Water 41(2):119-127.

17. US ATSDR (United States Agency for Toxic Substances and Disease Registry, (2007). Toxicological Profile for lead. U.S. Department of Health and Human Services. 1-582.

18. Alexieva D, Chobanova S \& Ilchev A (2007). Study on the level of heavy metal contamination in feed materials and compound feed for pigs and poultry in Bulgaria. Trakia J Sci 5(2): 61-66.

19. Adamse P, Van der Fels-Klerx HJ \& Jacob de J (2017). Cadmium, lead, mercury and arsenic in animal feed and feed materials-trend analysis of monitoring results. Food Addit Contam A 34(8): 1298-1311.

20. Prashanth L, Kattapagari KK, Chitturi RT, Baddam VR \& Prasad LK (2015). A review on role of essential trace elements in health and disease. $J$ NTR Univ Health Sci 4(2): 75-85.

21. EFSA (2004). Opinion of the Scientific Panel on Contaminants in the Food Chain on a request from the $1310 \mathrm{P}$. ADAMSE ET AL. Commission related to cadmium as undesirable substance in animal feed. EFSA $J$ 72: $1-24$. 